\title{
Molecular and Genetic Bases of Fruit Firmness Variation in Blueberry-A Review
}

\author{
Francesco Cappai ${ }^{\dagger}$, Juliana Benevenuto ${ }^{\dagger}$, Luís Felipe V. Ferrão ${ }^{\dagger}$ and Patricio Munoz * (D) \\ Blueberry Breeding and Genomics Laboratory, Horticultural Sciences Department, University of Florida, \\ Gainesville, FL 32611, USA; francesco.cappai@ufl.edu (F.C.); jbenevenuto@ufl.edu (J.B.); \\ lferrao@ufl.edu (L.F.V.F.) \\ * Correspondence: p.munoz@ufl.edu; Tel.: +1-352-273-4837 \\ + These authors contributed equally to this work.
}

Received: 3 August 2018; Accepted: 30 August 2018; Published: 5 September 2018

\begin{abstract}
Blueberry (Vaccinium spp.) has been recognized worldwide as a valuable source of health-promoting compounds, becoming a crop with some of the fastest rising consumer demand trends. Fruit firmness is a key target for blueberry breeding as it directly affects fruit quality, consumer preference, transportability, shelf life, and the ability of cultivars to be machine harvested. Fruit softening naturally occurs during berry development, maturation, and postharvest ripening. However, some genotypes are better at retaining firmness than others, and some are crispy, which is a putatively extra-firmness phenotype that provides a distinct eating experience. In this review, we summarized important studies addressing the firmness trait in blueberry, focusing on physiological and molecular changes affecting this trait at the onset of ripening and also the genetic basis of firmness variation across individuals. New insights into these topics were also achieved by using previously available data and historical records from the blueberry breeding program at the University of Florida. The complex quantitative nature of firmness in an autopolyploid species such as blueberry imposes additional challenges for the implementation of molecular techniques in breeding. However, we highlighted some recent genomics-based studies and the potential of a QTL (Quantitative Trait Locus) mapping analysis and genome editing protocols such as CRISPR/Cas9 to further assist and accelerate the breeding process for this important trait.
\end{abstract}

Keywords: firmness; Vaccinium; ripening; cell wall; crispy; quantitative genetics; breeding; molecular markers; genome editing

\section{Introduction}

Blueberry has been recognized worldwide for its health benefits due to its high content and wide diversity of polyphenolic compounds [1,2]. Polyphenolic compounds, especially anthocyanins, have been shown to have anti-oxidant, anti-inflammatory, anti-proliferative, anti-obesity, and neuroprotective properties [3]. Such health-related awareness has been driving an increase in demand for blueberries, which became one of the crops with the highest production trends. From 1996 to 2016, worldwide production has grown by $72.11 \%$ [4]. Currently, the United States of America is the largest producer, being responsible for around 48\% of the world's production in 2016 [4].

Most of the blueberry production is destined for the fresh market sector, which requires high-quality berries and postharvest longevity [5]. In order to maintain the fresh market standards, blueberries are usually hand-picked. However, hand-harvest labor accounts for $50 \%$ (or even more) of the production costs and raises concerns about its long-term availability [5-7]. In addition, fresh fruit handling by ill workers has been linked to foodborne illnesses in consumers [8]. Mechanical harvesting can mitigate the need of hand-harvest labor, decrease production costs, and foster further expansion of 
this healthy fruit. Wide adoption of machine harvesting for the fresh market is, however, currently limited to only a few commercial blueberry cultivars. Fruit firmness is one of the main determinant traits required to withstand the physical impacts during machine harvesting [6,7,9-11].

Blueberries are shipped to long-distance markets all over the world and softening and bruising fruits are among the most common defects causing shipment rejections [10,12]. Hence, firm berries are also critical for transportability and shelf-life longevity [10,11]. Moreover, a firm texture is one of the consumers' most appreciated features, being associated with the general concept of fruit freshness and quality [13-15]. Taken all together, fruit firmness is a key target for blueberry breeding as it benefits all stakeholders.

Firmness naturally declines during berry development, maturation, and postharvest ripening $[12,16,17]$. Understanding the biological mechanisms underlying fruit softening is essential to manipulate it without affecting other desirable aspects of ripening, such as color, flavor, aroma, or nutritional value [18]. Despite the natural softening during ripening, some plant genotypes appeared best at retaining firmness by the merit of having high initial firmness values [9]. Intraspecific (Vaccinium corymbosum L.) and interspecific (wild relatives) phenotypic variation has been reported, constituting breeding resources for firmness improvement $[6,19]$. In addition to firmness, a potentially separate phenomenon has been identified in blueberry: fruit crispiness. Crispy fruits are firmer and have higher bursting energy than standard fruits. Hence, crispiness is a distinct textural attribute that is also of high interest for the blueberry industry.

In this review, we presented recent advances in blueberry research regarding firmness changes during berry development and ripening. We summarized the extent of phenotypic variability of the firmness trait described in blueberry and its genetic parameters. New insights into these topics were achieved by using previously available data and historical records from the blueberry breeding program at the University of Florida. We also emphasized the first study attempting to implement marker-assisted selection (MAS) for this trait, through genome-wide association studies (GWAS). Finally, we discussed perspectives to further implement QTL mapping and genome editing technologies, such as CRISPR in blueberry.

\section{Physiological, Cellular, and Molecular Changes Affecting Fruit Firmness}

\subsection{Fruit Anatomy and Growth during Ripening}

Blueberries, as many berries of the Vaccinium genus, are false berries, because they are berry-like, but develop into a fruit without a stone from a single fertilized superior ovary [20]. Anatomically, the blueberry fruit develops from an inferior ovary. The endocarp is composed of five carpels with ten locules and five lignified placentae to which around 10-65 seeds are attached. The endocarp is surrounded by the mesocarp, which is composed of parenchyma cells along with rings of vascular bundles, with some stone cells unevenly distributed $[15,21]$. The epicarp originates from the flower calyx. Delimited by a ring of vascular bundles, the hypodermal layer contains the anthocyanin pigmentation. Above this, there is a single layer of epidermis without stomates. The epidermis is covered by a cuticle and an epicuticular waxy bloom that overshadows the purple-black skin of blueberry fruits, creating the characteristic light-blue color [22].

Berry growth commonly exhibits a double sigmoid growth curve, with a lag stage between two phases of active growth [23,24]. The first growth stage occurs after syngamy and is characterized by a rapid cell division, leading to a rapid expansion of the pericarp. In the second stage (lag stage), embryo and endosperm tissues mature, while the development of the pericarp is retarded with no evident increase in berry size and no changes in color. In the third stage, a second rapid pericarp development takes place due to cell enlargement until the berry is fully ripe. Changes in size are accompanied by changes in color (from green, pink, to blue), and biochemical changes such as increases in $\mathrm{pH}$, sugar composition, soluble solid content, volatiles, and texture. The fruit development and ripening process usually takes 45-90 days, depending on the cultivar and external factors [25]. 


\subsection{Ripening-Associated Physiological Changes}

Physiological changes associated with ripening are a major determinant of berry firmness, as the fruit softens as it matures. The ripening process is coordinated by a complex network of endogenous hormones. For many fleshy fruit plant species, the phytohormone ethylene is the main ripening agent [26]. Climacteric fruits show a concomitant increase in respiration and ethylene biosynthesis upon initiation of ripening [27]. Ethylene perception and signal transduction can affect fruit color, sugar and acid content, and firmness [28]. This process is however not linear: it varies over time and the abovementioned ripening changes can be disjointed [28,29]. Currently, there is no consensus on whether blueberry is a climacteric fruit or not. Some studies suggested that blueberry is indeed a climacteric fruit $[30,31]$, with also increased anthocyanin accumulation upon ethylene application in some cultivars [32]. Chiabrando and Giacalone (2011) [33] proposed that 1-methylcyclopropene (1-MCP), a compound that hinders cellular ethylene perception, has the potential for controlling ripening in blueberry. Fruits from the cultivar "LateBlue" showed reduced post-harvest weight loss and lower total soluble solid content after 1-MCP treatment, indicating a slower ripening effect [33]. In line with these findings, Wang et al. (2018) [34] also showed that an ethylene absorbent treatment prevented ethylene production, inhibited cell wall degrading enzymes, and reduced softening of blueberry fruit. However, conversely, other studies suggested that 1-MCP application has no inhibition effect on ripening of post-harvested blueberries $[35,36]$, and might decrease fruit firmness $[37,38]$.

In non-climacteric fruits, where no burst in ethylene production is observed, abscisic acid (ABA) seems to have a stronger role during fruit ripening [27]. However, similarly to what has been reported for ethylene, studies addressing the effects of ABA in blueberry fruit firmness also showed contradictory results. Sun et al. (2013) [39] reported that ABA application was able to promote fruit softening; whereas Buran et al. (2012) [40] observed the opposite phenomenon.

As of now, the role of ethylene and ABA phytohormones in blueberry fruit ripening, as well as the question if blueberry is a climacteric or non-climacteric fruit remains unclear. However, it is noteworthy how multiple studies have reported different effects of ethylene, as inhibitor or promoter of fruit ripening, and also cultivar-specific responses, suggesting the need for more studies in this field and that distinct mechanisms might exist among blueberry genotypes.

\subsection{Molecular and Architectural Changes in Plant Cell during Fruit Ripening}

Ripening is also accompanied by compositional and architectural changes in the plant cell, mainly at the primary cell wall and middle lamella through the action of carbohydrate active enzymes, ultimately affecting fruit firmness [41]. Plant cell wall is a complex matrix of polysaccharides, mainly composed of pectin, hemicellulose, and cellulose. The cellulose microfibrils are cross-linked through hydrogen bonds with hemicellulose, thereby forming a complex network that provides tensile strength to the primary cell wall [42]. The pectin matrix is interwoven with the cellulose-hemicellulose network in the primary cell wall and also composes the middle lamella, being a major physical mediator of cell adhesion and separation [43].

Noncellulosic sugars have been implied in regulating firmness as they provide physical support by connecting at cellulose myofibrils in cell walls [44]. In particular, depolymerization, and solubilization of hemicellulose and pectin are the processes generally associated with cell wall disassembly and fruit softening during ripening [41,45-48]. In blueberry, hemicellulosic polymers undergo a significant depolymerization and a moderate solubilization throughout all five stages of ripeness analyzed, indicating that hemicellulose modification might be the main cell wall alteration during blueberry ripening [49]. The pectin matrix also shows increased solubilization mostly at the initial and intermediate stages of ripening and little reduction in polymer size occurred [49]. Pectin solubilization was also observed during blueberry post-harvest storage [17]. Interestingly, calcium application has been reported to enhance firmness and post-harvest quality of blueberries [50,51]. Angeletti et al. (2010) [51] speculated that the increase in calcium content might decrease pectin solubilization, while not affecting hemicellulose in blueberry. In many ripe fruits, most of the cell-to-cell adhesion is 
conferred by calcium-pectate cross-links in the middle lamella, producing a semi-rigid gel that increases cell wall stiffness and hinders cell wall disassembly $[41,43,52,53]$. In general, the role of calcium in cell wall solidity and post-harvest quality is well established in a number of crops, such as apple (Malus domestica Borkh) [54-56], grape (Vitis vinifera L.) [57-59], and strawberry (Fragaria $\times$ ananassa Duchesne) [60-62], and seems to be relevant also in blueberry.

The degradation of cell wall polysaccharides depends on the action of enzymes with distinct spectra of activities. A panel of enzymes involved in carbohydrate synthesis, modification, and breakdown are collectively named as carbohydrate-active enzymes (CAZymes). The CAZy database is currently the most comprehensive database (http:/ / www.cazy.org) for CAZyme proteins [63]. Hence, to further investigate the role of CAZymes during blueberry ripening, we retrieved the putative encoding genes by sequence similarity of the predicted blueberry proteome with the CAZy database and the transcriptional profile of five stages of berry fruit development (pad, cup, green, pink, and ripe fruits) from Gupta et al. (2015) [64]. Distinct patterns of expression were observed for the genes into the six classes of CAZymes throughout the fruit development process (Figure 1). Up-regulated CAZymes encoding genes in pink and ripe fruits in relation to early stages are highlighted as they can be involved in cell wall disassembly, allowing cell expansion and fruit growth, but later cause fruit softening.

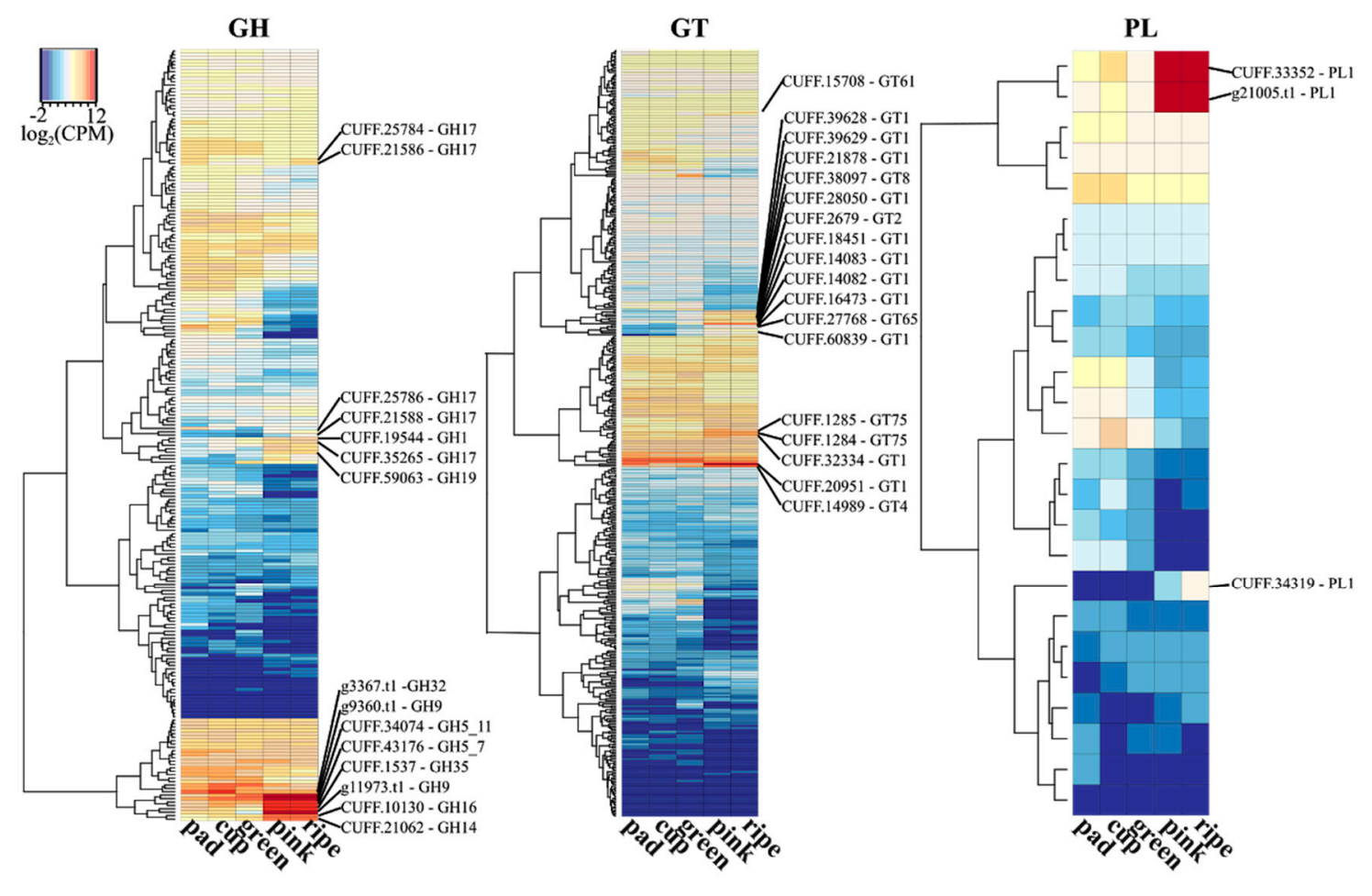

Figure 1. Cont. 


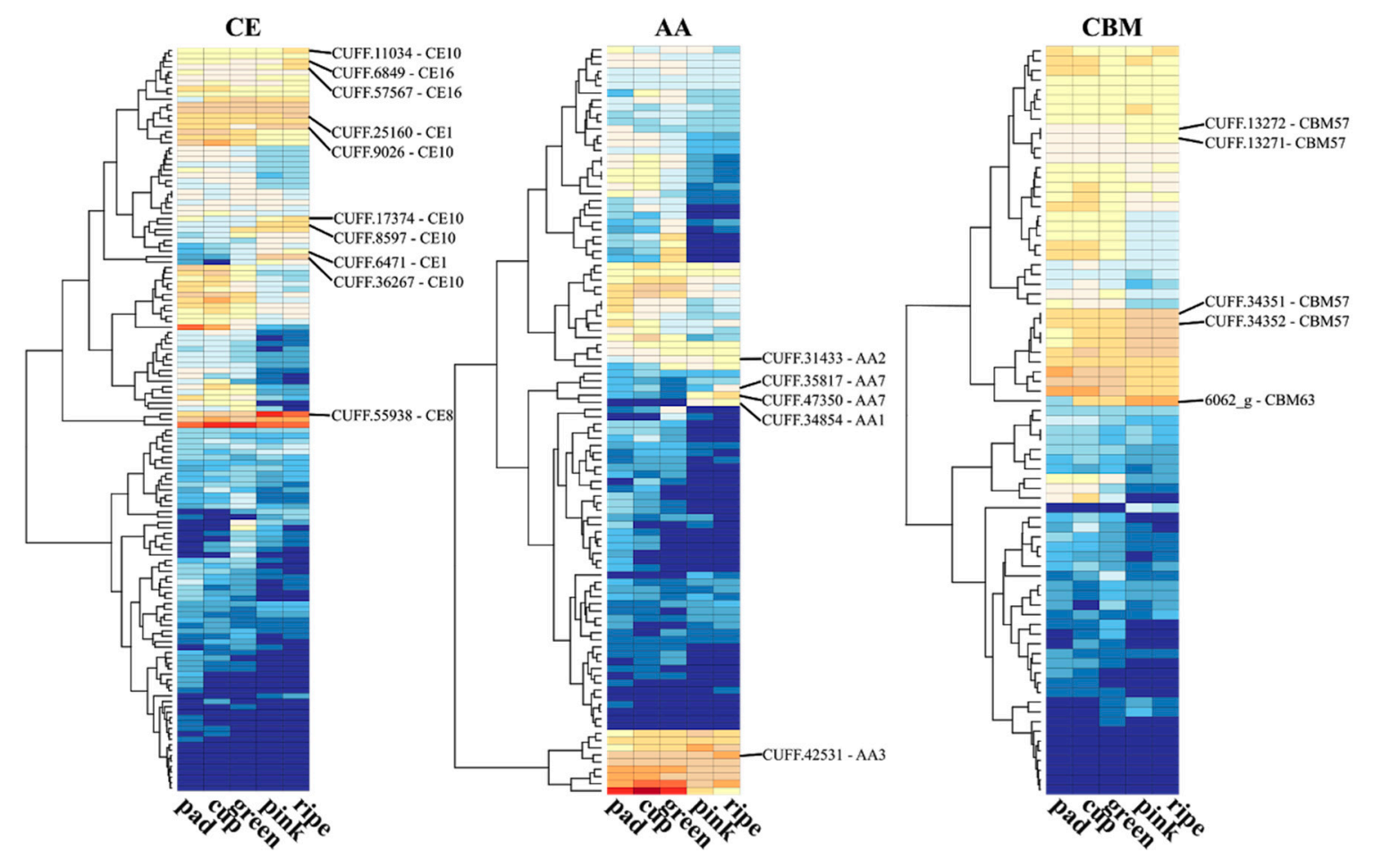

Figure 1. RNA-seq transcriptional profile of CAZymes during five stages of berry fruit development and ripening. The predicted blueberry proteome was screened for CAZYmes [65] using Hmmscan from the HMMER v3.1b2 package (http:/ / hmmer.org/) and the dbCAN HMM profile database [66]. The hmmscan-parser script provided by dbCAN was used to select significant matches. CPM (counts per million mapped reads) values from five developmental berry stages of a RNA-seq experiment were retrieved from Gupta et al. (2015) [64] from the bitbucket repository (https://bitbucket.org/ lorainelab/blueberrygenome). The CPM mean value of each gene was calculated from three replicates of each stage available. The $\log _{2}$-transformed CPM mean values were used to plot the gene expression of CAZymes across the five stages. The R package "gplots" with "heatmap.2" function was used to generate the heatmaps using the parameter "dendrogram $=c($ "row")" to cluster genes according to hierarchical clusters. Classes and modules of CAZymes are represented by GH (glycoside hydrolases), GT (glycosyl transferases), PL (polysaccharide lyases), CE (carbohydrate esterases), AA (auxiliary activities), and CBM (carbohydrate-binding modules) (For more details, see: http://www.cazy.org/). Genes up-regulated at pink and/or ripe stages in relation to early stages are highlighted and the family number reported.

Glycoside hydrolases (GHs) catalyze the hydrolysis of glycosidic bonds between carbohydrates or between a carbohydrate and a non-carbohydrate moiety. Among the up-regulated GHs families, we found five beta-glucosidases (GH family 17) blueberry encoding genes (Figure 1). GH 17 family members have been associated with cell wall degradation and remodeling, hydrolysis of phytohormones (such as ABA), pathogen resistance, and in aromatic acid biosynthesis pathways [67]. In banana (Musa spp.), more than a two-fold enhanced expression of genes in the GH 17 family was detected in the ripe fruits compared to unripe ones [67]. Others interesting GH enzymes detected were endo-1,4- $\beta$-glucanases (GH7, GH9), exo-1,4- $\beta$-glucanases (GH1), endo-xyloglucan transferase (GH16), and endo-1,4- $\beta$-xylanase (GH11) that probably act on hemicellulose depolymerization or hydrolyzing the crosslinks between microfibrils, thereby disassembling the cellulose-xyloglucan network $[68,69]$. Exo- $\beta$-galactosidases from GH family 35 has also been associated with depolymerization of pectins. These enzymes can cause cell wall loosening during growth, and cell wall degradation during ripening and senescence $[67,70]$. Up-regulated invertase (GH32) and amylase (GH14) generate reducing sugar monomers, which may be responsible for the increased sweetness during fruit ripening [71]. 
In blueberry, cold storage was shown to maintain firmness probably due to the reduced activities of such enzymes at lower temperatures [36].

Polysaccharide lyases (PLs) cleave uronic acid-containing polysaccharide chains. Three pectate lyase (PL1 family) genes were up-regulated during blueberry ripening (Figure 1). PL1 enzymes degrades de-esterified pectin in the primary wall. In tomato (Solanum lycopersicum L.), the silencing of a PL-encoding gene inhibited pectin solubilization and depolymerization, maintaining the firmness without affecting other aspects of ripening [18,72]. In line with this, a gene in the carbohydrate esterase (CEs) class, encoding a pectin methylesterase (CE8), was also up-regulated in blueberry (Figure 1). CE8 enzymes alter the pectin structure by catalyzing the demethyl esterification of pectin, which then becomes cleavable by pectate lyases [18]. Glycosyltransferases (GTs), which catalyze the transfer of sugar moieties forming glycosidic bonds, have been associated with cell wall polysaccharide synthesis (GT2, GT8, GT61, GT65, GT75), sucrose synthesis (GT4), and anthocyanin modification and formation of glycosylated volatile compounds during fruit development and ripening [73,74]. Enzymes with auxiliary activities (AAs) that act in conjunction with CAZymes and genes with a carbohydrate-binding module were also found up-regulated at pink and blue stages of blueberry ripening (Figure 1).

In addition to changes in cell wall composition and disassembly, reduction in turgor pressure during ripening can also cause shrinkage and loss of firmness. Reduction in the turgor is likely due to the accumulation of osmotic solutes in the apoplast and to water loss by the fruit [41] and has been reported in stored blueberries [75]. Recent studies have also shown the roles of the stem scar size/transpiration and cuticular wax composition and thickness in water loss and maintenance of the post-harvest firmness in blueberry $[22,76,77]$. Among the blueberry fruit cuticular triterpenoid composition, the ursolic acid content at harvest was positively correlated to weight loss and softening after storage, offering an interesting target for further studies [77]. The importance of containing water loss is also supported by the fact that coating fruits with oily films, which create a semi-permeable barrier around the fruit, prevented firmness decay [78,79].

The findings reported herein offer some insights into the molecular bases of fruit softening during ripening and postharvest storage of blueberries. Further functional validation of the differentially expressed CAZymes can provide good candidates for the implementation of genome editing tools aiming at firmness maintenance.

\subsection{Fruit Tissue and Cellular Differences Underlying Firmness Variation}

Several components of fruit tissues have been reported to contribute to firmness and texture variation across genotypes, including cell type, size, shape, packing, cell-to-cell adhesion, extracellular space, and cell wall thickness $[15,80,81]$. In blueberry, differences regarding the number and organization of lignified cells with thick secondary cell walls, such as stone cells in the mesocarp, have been hypothesized to strengthen the surrounding flesh tissue and contribute to fruit firmness variation among genotypes [81,82]. Sensorial studies of genotypes ranging from soft to crisp suggested that the crisp texture may be related to the blueberry skin toughness rather than the flesh [83]. Histological analyses of cell type, area, and structure of the outermost cell layers of genotypes varying in textural attributes showed that crispy genotypes had a smaller average cell area compared with standard-textured genotypes in mature fruits and no difference in the frequency of stone cells in the layers beneath the epidermis was detected [15].

\section{Genetics and Breeding of Blueberry Firmness}

\subsection{Measuring Firmness}

Firmness has also been a key breeding target for many fruit crops such as apple, pear (Pyrus communis L.), peaches (Prunus persica L. Batsch), etc. Historically, firmness in these crops has been measured using a hand-held penetrometer [84-88] (e.g., Magness-Taylor's and Effe-gi testers) and, more recently, an Instron-mounted probe (Instron Corporation, Norwood, MA USA) [89-92]. 
A number of attempts has been undertaken to upscale firmness measurement in these crops through imaging and acoustic studies, with partially successful results [93-98]. However, these methods were not translated to blueberry, possibly due to the constraints imposed by the small size of the blueberry fruit compared to pear or apple.

In blueberry, fruit firmness has been traditionally evaluated by chewing texture, with the assignment of a subjective and qualitative score ranging from "soft" to "firm" [99]. More recently, automated equipment allowed the objective and quantitative evaluation of fruit firmness. FirmTech instruments (FirmTech I and II, Bioworks, Wamego, KS, USA) are the most commonly used for blueberry and firmness is a measure of the compression force $(\mathrm{g})$ required to deflect the surface of the fruit one millimeter. A texture analyzer instrument (Texture Technologies Corporation, Scardale, NY, USA) has also been increasingly used and might give more precise results than FirmTech, especially when trying to dissect skin and pulp firmness. However, these equipment present differences in probe sizes and shapes, making the standardization challenging [83,100-103]. Hence, in this review, we only included measurements obtained with FirmTech instruments as more data were available [6,14,37,80,88-138].

Regarding the firmness trait evaluation, an issue that has not been addressed yet is how many berries should be sampled to accurately represent a genotype. Each study has used a distinct number of samples, ranging from five to hundreds of berries. Assuming that sample size is an important element for research design and validation, we assessed how the mean firmness varied across different sample sizes considering four cultivars (Figure 2). We collected 200 berries from each genotype and performed 1000 resamplings considering 12 different sample sizes. The mean and variance values computed for the 200 berries were considered our "true" population parameters. As expected, small sample sizes resulted in higher variance in the mean firmness values of a genotype than large sample sizes (Figure 2a). The fraction of the confidence intervals $(\mathrm{CI}=90 \%)$ that encompassed the "true" population mean ranged across the sample sizes for all cultivars (Figure $2 b$ ) and, the smaller the sample size, the more values out of the CI were generated. For a sample size of five berries and for all cultivars, we observed that around $25 \%$ of the estimates did not lie in the confidence interval of $90 \%$, which means that in a breeding population composed of 1000 individuals around of 250 measures of firmness would be inaccurate, hence affecting downstream analyses. By sampling 25 berries, the amount of outlier estimates dropped to about $10 \%$ considering the confidence interval and it is also a sample size operationally feasible, since FirmTech devices are able to run 25 berries per round of analysis.

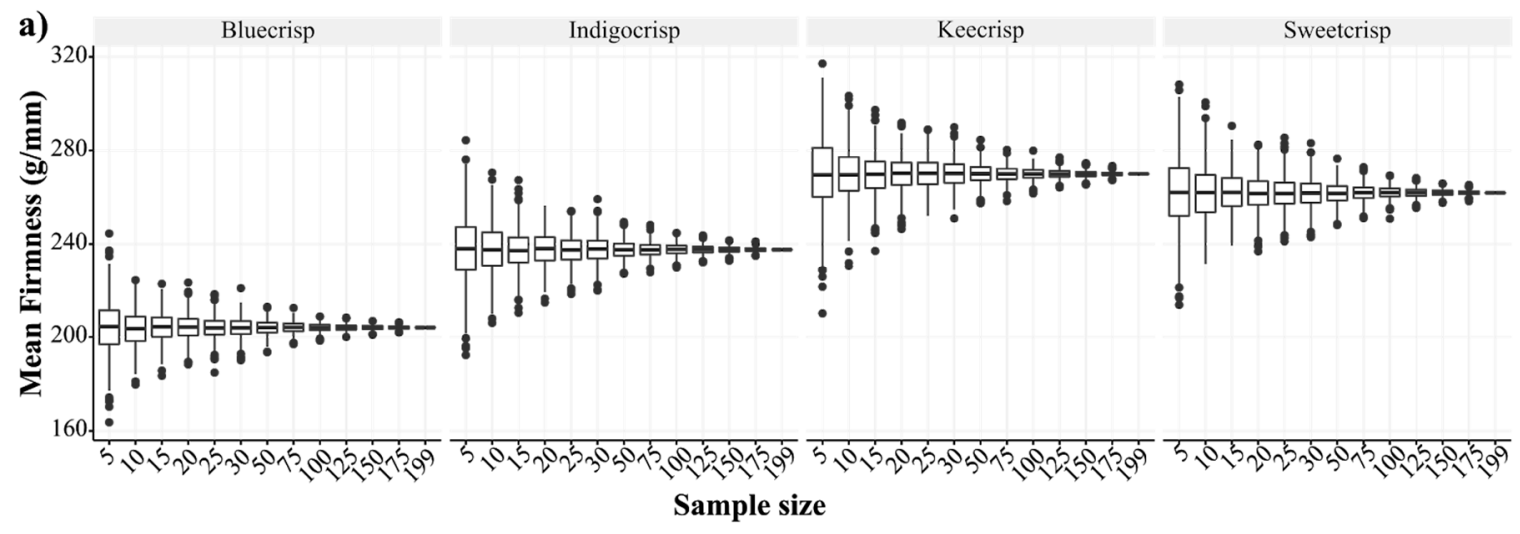

Figure 2. Cont. 


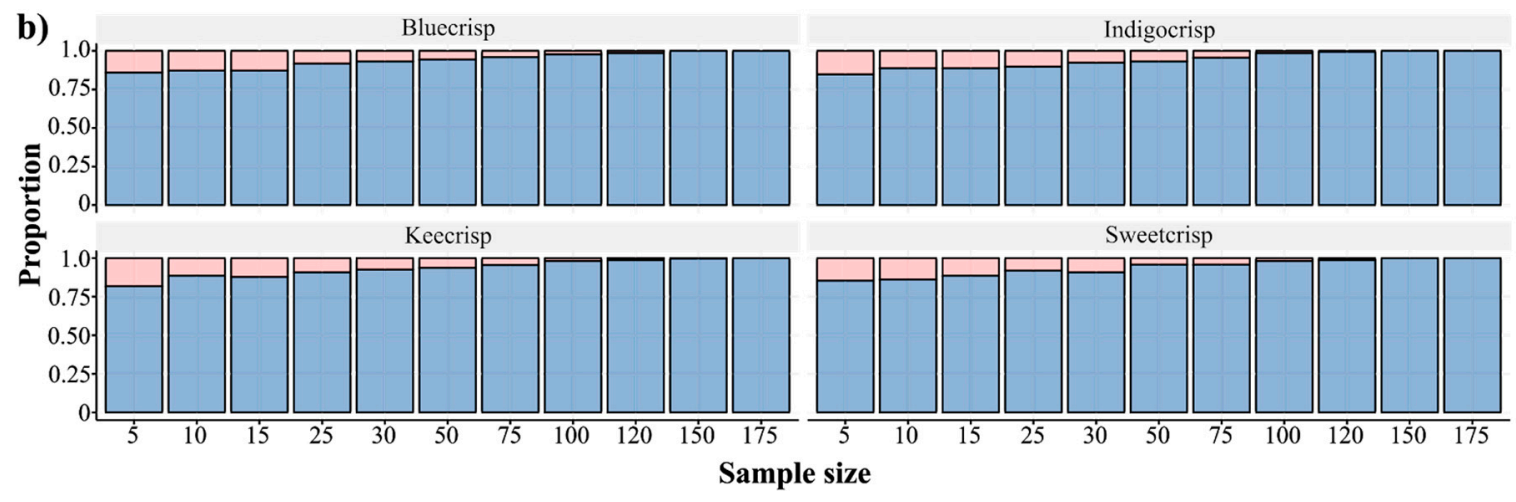

$\square$ FALSE $\square$ TRUE

Figure 2. Number of berry samples to estimate the firmness value of a genotype. (a) Boxplot of the mean firmness values considering different sample sizes for four SHB cultivars. Briefly, 200 mature berries of each cultivar were collected and measured for firmness using the FirmTech II device (BioWorks Inc., Victor, NY, USA). To describe the effect of the sample size on the mean value, 1000 resamplings were carried out considering 12 different sample sizes (5-199) and the mean firmness value was computed at each sampling round. (b) Fraction of the confidence intervals that encompassed the "true" mean parameter, computed assuming that 200 berries are enough to well-represent a genotype, across different sample sizes and four different cultivars. We performed the same resampling process but recording the parameters that laid in a confidence level of $90 \%$.

\subsection{Phenotypic Variation and Breeding Improvement in Fruit Firmness}

Heritable phenotypic variation is critical for breeding selection to be effective. Enough phenotypic variation for firmness has been observed within breeding populations, among blueberry cultivars, and wild species $[6,19,139]$. Herein, we performed a survey of firmness values for a wide range of cultivars, representing the main cultivated blueberry types. Cultivated blueberry belongs to section Cyanococcus of the genus Vaccinium into the Ericaceae Family and comprises distinct species and hybrids with specific ploidy, plant architecture, and chilling hour requirements. The main blueberry type used for commercial production is a tetraploid highbush $(2 n=4 X=48)$, with Vaccinium corymbosum $\mathrm{L}$. as the primary species in its genetic background. Highbush blueberries are further classified according to their chilling requirements as Northern Highbush Blueberry (NHB) and Southern Highbush Blueberry (SHB) $[140,141]$. NHB is native to Eastern North America and is the most widely planted type in temperate climates (600-1200 h of chilling between 0 to $\left.7^{\circ} \mathrm{C}\right)$. SHB was originally developed by the introgression of an evergreen Florida native species (Vaccinium darrowii Camp) into the NHB background, leading to reduced chilling requirements (100 to $600 \mathrm{~h}$ ) and, therefore, being adapted to warmer climates such as southern US [142-144]. Rabbiteye blueberry is another commercially important species, hexaploid Vaccinium ashei Reade, which tolerates a range of soil and warm climatic conditions and are also planted in the Southern US. Lowbush blueberry is another tetraploid species (Vaccinium angustifolium Aiton), whose wild fruits are harvested commercially in New England. The cultivated half-high blueberry $(\mathrm{HH})$ was originated from a cross between NHB and lowbush and also requires lower temperatures to flower.

In this survey, we collected berry firmness data from scientific papers that used the FirmTech instrument, except for those reporting experimental treatments such as insect damage, extreme growth conditions, etc. (see Supplementary Materials for more details). The mean firmness value of each cultivar was plotted according to their respective release year (Figure 3). High diversity of firmness values can be observed between and within blueberry types (Figure 3a). As the NHB breeding began earlier (1906), more NHB cultivars are displayed. The first released NHB cultivars, "Harding" and "Rubel", were actually selected from the wild. "Pioneer" was the first cultivar released after breeding efforts in 1920 [145]. SHB breeding programs are more recent and the first cultivar "Sharpblue" was 
released in 1975 [146]. The NHB cultivar "Herbert" presented the lowest firmness value, while the SHB cultivar "Sweetcrisp" presented the highest firmness value among all blueberry types (Table 1).

a) ONHB ORabbiteye OSHB OHH

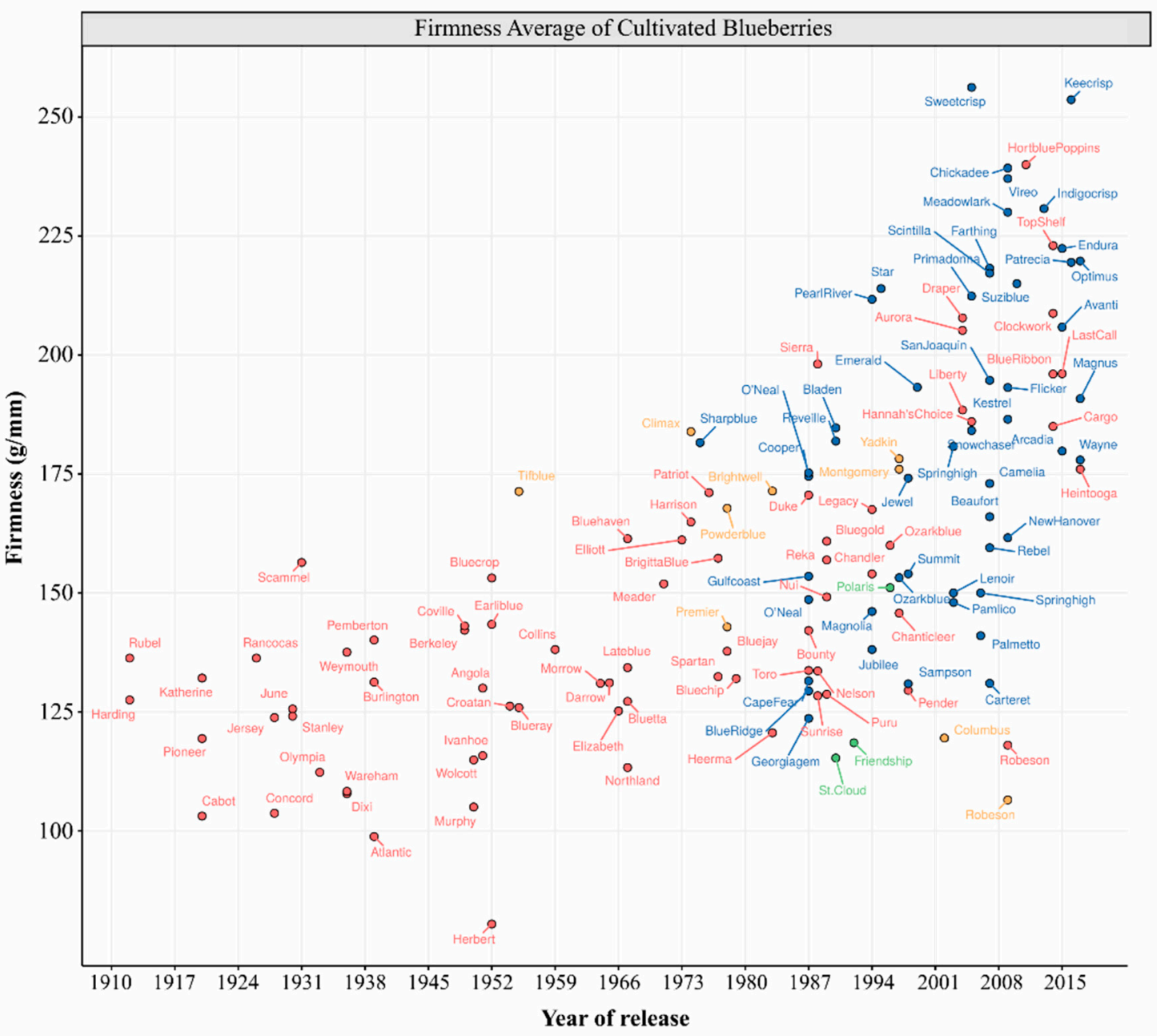

b)

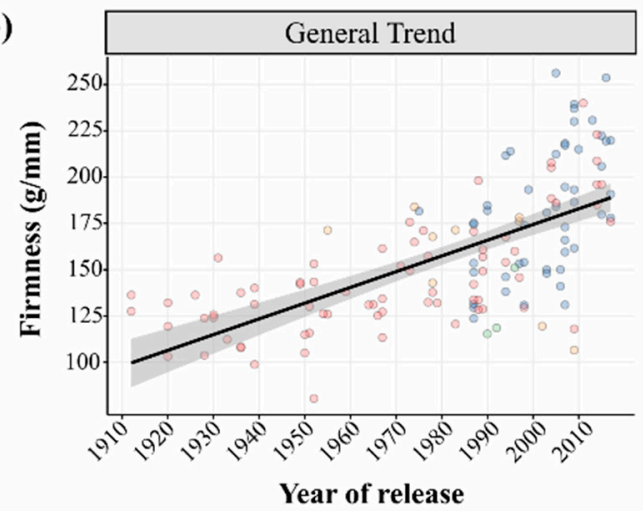

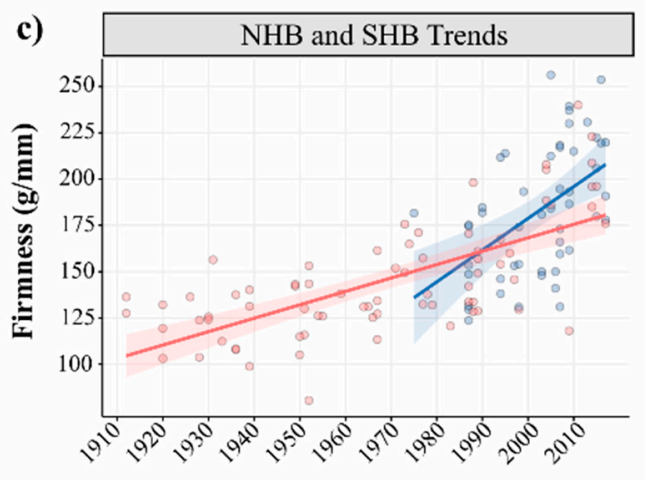

Year of release

Figure 3. (a) Blueberry cultivar firmness values by year of release. Plot was created using historical data recorded by the blueberry breeding program at the University of Florida and data from previous blueberry publications (for details, see Supplementary Material); (b) Linear regression on the firmness values as a function of the year of cultivar release with a slope of 0.84 ; (c) Linear regression on the firmness values as a function of the year of cultivar release for NHB (slope of 0.72) and SHB (slope of 1.71), separately. 
Table 1. Summary of firmness measurements for distinct types of cultivated blueberry. For more detailed information, see Supplementary Materials.

\begin{tabular}{cccccc}
\hline Type $^{*}$ & n & Mean & St. Dev & Maximum & Minimum \\
\hline SHB & 50 & 183 & 35.18 & 256 (Sweetcrisp) & 124 (Georgiagem) \\
HH & 3 & 128 & 19.79 & 151 (Polaris) & 115 (St. Cloud) \\
NHB & 74 & 145 & 31.22 & 240 (Hortblue Poppins) & 80 (Hebert) \\
Rabbiteye & 9 & 157 & 27.87 & 184 (Climax) & 106 (Robeson) \\
\hline
\end{tabular}

* Southern Highbush (SHB), Northern Highbush (NHB), Half-high (HH), and Rabbiteye cultivars.

The positive regression slope in Figure $3 \mathrm{~b}$ showed a general trend towards firmness improvement throughout the years, i.e., on average, modern cultivars are firmer than first-released genotypes. This general trend is expected, as firmness is a key target trait in blueberry breeding programs and also suggested that significant genetic gain has been achieved. In Figure 3c, we can also observe a trend towards higher firmness values of SHB in relation to NHB, although SHB also exhibit slighter higher variation (Table 1). Some studies suggested that cultivars with a higher percentage of $V$. darrowii (evergreen blueberry) and $V$. ashei (rabbiteye) ancestry often possessed higher firmness values, which would be the case of SHB; while cultivars with $V$. angustifolium (lowbush) ancestry presented softer fruits than the average, as also observed for HH blueberries in Figure 3a [6,99,139]. However, such conclusions can be misleading since the firmness values retrieved herein were collected under distinct experimental conditions and locations, using varying numbers of berries and equipment versions (see Supplementary Materials).

It is also noteworthy that cultivars considered crispy, such as "Sweetcrisp" (SHB), "Keecrisp" (SHB), "Indigocrisp" (SHB), "Hortblue Poppins" (NHB), showed the highest firmness values (Figure 3a). Blaker et al. (2014) [107] had also found a correlation among compression and bioyield force measures with sensory scores for bursting energy, flesh firmness, and skin toughness, distinguishing crisp from standard-texture SHB genotypes. We should also mention that in food science jargon crunchiness and crispiness are two different phenomena based on sensory, acoustic and vibrational cues [147]. However, no study has formally addressed whether blueberry cultivars are crispy or crunchy.

\subsection{Quantitative Genetics of Firmness Trait in SHB Blueberry Breeding}

Blueberry breeding programs have relied on pedigree information and cross-pollination breeding methods to increase the mean phenotypic performance in selected populations [141]. Phenotypic recurrent selection has been used as a primary breeding strategy in blueberry, where elite parents are selected at each generation for intercrossing, the progenies are evaluated over the course of multiple years in the field, and a cultivar consists of a superior individual cloned by cutting propagation. During this process, quantitative genetics constitute the fundamental basis to guide breeding efforts. Many agronomically important traits, including firmness, display a continuous phenotypic variation in a given population, likely governed by the joint action of numerous genes and environmental factors. The continuous distribution of such complex traits resulted in phenotypes that do not show simple Mendelian inheritance, requiring a quantitative genetics framework of analyses. Quantitative models dissect the observed phenotypic value of an individual into genetic and environmental components in order to estimate the heritable and non-heritable portions of the variation.

Quantitative genetic studies in blueberry have focused on three main challenges: (I) identify the elite genotypes to be used as parents in future crosses [19,148-151]; (II) estimate genetic parameters such as heritability, phenotypic and genetic correlations, and predict the expected change in a trait in response to selection-the breeder's equation $[19,148]$ and (III) estimate the genotype-by-environment $(\mathrm{G} \times \mathrm{E})$ interaction $[13,19,152,153]$. Genetics studies in blueberry have been reported for distinct traits; however, to our knowledge, only Cellon et al. (2018) [19] have investigated the firmness trait. In order to guide the selection of firmer genotypes and estimate genetic parameters, Cellon et al. (2018) [19] 
found moderate-to-high values of heritability for this trait with large variability across the years ( 0.43 in 2014 and 0.70 in 2015). The presence of variability across the years indicated genotype-by-year interaction, while the magnitude of the heritability values suggested potentially rapid gains in response to selection.

Phenotypic expression of quantitative traits is influenced by environmental conditions, leading to variations across locations and years that, ultimately, impact the ranking of the genotypes. Despite its relevance, there are few studies addressing $\mathrm{G} \times \mathrm{E}$ for the firmness trait in the blueberry literature. Motivated by this, we performed an initial assessment of $\mathrm{G} \times \mathrm{E}$ interaction in SHB using the dataset recorded by the breeding program at the University of Florida for six cultivars, planted in four locations, from 2011 to 2017 (Figure 4a). Based on an analysis of variance (ANOVA), the G $\times \mathrm{E}$ interaction effect was statistically significant $(p<0.05)$. The interaction plot suggests that the crispy cultivars, "Indigocrisp" and "Sweetcrisp", are more stable across the environments than the non-crispy ones (Figure $4 \mathrm{~b}$ ). This preliminary screening suggests that $\mathrm{G} \times \mathrm{E}$ interaction impacts fruit firmness. From a theoretical point of view, ignoring the heterogeneity caused by different environments can bias the prediction of breeding values and negatively affect the estimates of genetic variances. For practical purposes, such effect directly affects the selection of elite materials and decreases genetic gains along breeding cycles [154].

a)

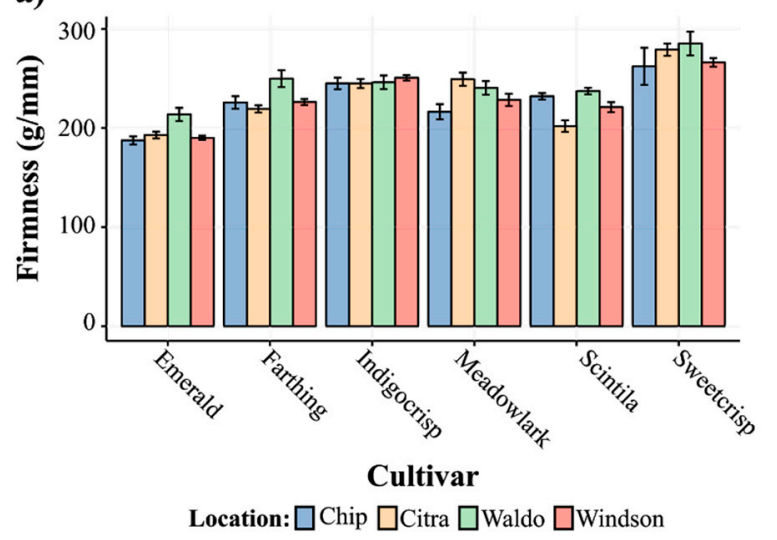

b)

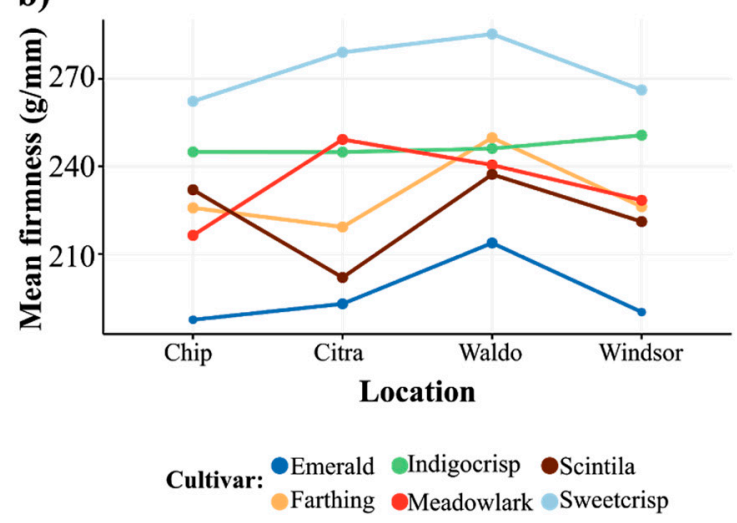

Figure 4. Genotype-by-environment interaction in SHB using the historical data recorded by the breeding program at the University of Florida. (a) Average of firmness for six cultivars, evaluated across four locations, during seven years; (b) Interaction plot showing the changes in firmness profile for six cultivars across four locations.

\subsection{Genomics Tools for Fruit Firmness Improvement}

Genomics-based strategies are increasingly being used to assist crop improvement. Advances in next-generation sequencing (NGS) and genotyping technologies have enabled high-throughput and relative low-cost identification of single-nucleotide polymorphisms (SNPs). By using thousands of markers spread throughout the genome, genome-wide association studies (GWAS) and genomic selection (GS) methods are becoming popular in many crop species [155]. GWAS is a methodology that investigates genetic variants in a large and genetically diverse population, testing each SNP for association to phenotypes of interest [156]; while GS uses all markers simultaneously to predict the breeding value of individuals [157]. Despite the potential of these approaches to accelerate breeding programs, there are remarkably few studies attempting to implement GWAS or GS models in blueberry.

A recent GWAS in SHB was the first attempt to identify the genetic basis of firmness variation in a breeding population [158]. SNP-firmness associations were detected for tetraploid (five associations) and diploid (three associations) gene action models only under a less stringent threshold (q-value of 0.1). Out of those, two missense variants were identified, one at a gene encoding a ubiquitin-like-specific cysteine proteinase (CUFF.36470.1) and another at a gene encoding 
a S-adenosyl-L-methionine-dependent methyltransferase (SAM-MTase) (CUFF.1480.1). Cysteine proteinases have been shown to act as post-transcriptional regulators of ripening-related proteins in tomato [159] and cysteine proteinases were also differentially expressed between firm and soft strawberry cultivars [160]. SAM-MTases catalyze transmethylation reactions in various biomolecules, acting in the biosynthesis pathway of ethylene and polyamines, which also have important roles during the ripening process and may affect fruit firmness [161-165]. Hence, some of the significant SNPs were detected within biologically plausible candidate genes affecting the trait [158]. However, individual markers explained a small portion of the phenotypic variation (less than 3.46\%). These results suggested that firmness is indeed a quantitative trait, whose phenotypic expression depends on the cumulative actions of many genes with small effects and their interaction with environment. However, assuming that firmness and crispiness are correlated traits, these results might conflict with the results of Blaker (2013) [83], where crispiness segregation pattern fit the expected ratio for a monogenic trait. Ferrão et al. (2018) [158] also raised the concern that controlling for population structure in the GWAS model can strongly reduce the statistical power to detect associations when phenotypes are correlated with relationship. In this scenario, a QTL mapping would be a more suitable approach for detecting loci with large effects.

Another breakthrough in the plant breeding field is the CRISPR/Cas9 (and related variants) technologies. CRISPR/Cas9 is a molecular system composed of an endonuclease capable of precisely cutting a targeted genomic DNA by matching a pre-designed guide RNA (gRNA). Extensive research has shown that this system can be customized to inactivate, edit, or insert a gene of interest [166-168]. This technology is especially useful for monogenic traits. A successful example was the CRISPR-mediated knock-out of a canker-susceptibility gene in citrus, generating a resistant plant [169]. This technique can also be used for improving polygenic traits, however, with less evident effects [170]. To our knowledge, no study has been published applying CRISPR technologies in blueberry to date. Editing the blueberry genome for improving firmness faces two major challenges: (I) detect a candidate region with large effects on fruit firmness to be edited and (II) optimize tissue culture protocols for the species to get high editing efficiency.

We also reinforce that the absence of a high-quality reference genome for blueberry imposes additional challenges for the implementation of genomics tools. The current available genome is very fragmented, with 11,797 scaffolds and N50 of 269,026 in the 2015 version, and many predicted genes are incomplete [64]. Improving the genome contiguity by using long reads (e.g., PacBio or Nanopore sequencing) and scaffolding tools (e.g., linkage map, optical map, Hi-C, 10X Genomics Chromium, linked-reads), as well as sequencing different types of blueberries will benefit the entire blueberry research community.

\section{Conclusions and Perspectives}

High fruit firmness values are important for the whole blueberry industry chain. Among the main benefits, firmness is a key trait for the wide implementation of machine harvesting for fresh market, which will reduce financial and labor concerns. Considerable genetic gains have been achieved throughout the history of blueberry breeding, with modern cultivars being, on average, firmer than first-released genotypes. Despite the importance of this trait, the number of genetic and molecular studies reported in the literature is still modest. Recent insights through RNA-seq and GWAS analyses highlighted the role of cell wall degrading enzymes, cysteine proteinase, and SAM-MTase in fruit firmness variation across developmental stages and across genotypes. For the implementation of marker-assisted selection in order to accelerate the breeding process, new experimental designs are required. We highlighted the more accurate measurements of the trait by using higher number of berry samples per genotype, a broader population panels for GWAS and/or a QTL mapping approach to detect loci with large effects on firmness variation, investigate the potential of GS to predict firmness; and establish CRISPR protocols for the species. More studies in these areas have the potential to unlock an era of faster and more efficient breeding tools for this healthy and high-value fruit crop. 
Supplementary Materials: The following are available online at http:/ /www.mdpi.com/2073-4395/8/9/174/s1, Table S1: Fruit firmness survey for four cultivated blueberry types.

Author Contributions: F.C. performed the literature survey of firmness values. L.F.V.F. and J.B. performed the data analyses and interpretation. F.C., J.B., L.F.V.F., and P.M. wrote the paper. P.M. conceived and supervised writing. All authors approved the final manuscript.

Funding: This work was funded by the UF royalty fund generated by the licensing of blueberry cultivars.

Conflicts of Interest: The authors declare no conflict of interest.

\section{References}

1. Szajdek, A.; Borowska, E.J. Bioactive Compounds and Health-Promoting Properties of Berry Fruits: A Review. Plant Foods Hum. Nutr. 2008, 63, 147-156. [CrossRef] [PubMed]

2. Rodriguez-Mateos, A.; Feliciano, R.P.; Cifuentes-Gomez, T.; Spencer, J.P.E. Bioavailability of wild blueberry (poly)phenols at different levels of intake. J. Berry Res. 2016, 6, 137-148. [CrossRef]

3. Norberto, S.; Silva, S.; Meireles, M.; Faria, A.; Pintado, M.; Calhau, C. Blueberry anthocyanins in health promotion: A metabolic overview. J. Funct. Foods 2013, 5, 1518-1528. [CrossRef]

4. The Food and Agriculture Organization of the United Nations -FAOSTAT. Available online: http:/ / www. fao.org/faostat/en/\#data/QC (accessed on 17 May 2018).

5. Gallardo, R.K.; Stafne, E.T.; DeVetter, L.W.; Zhang, Q.; Li, C.; Takeda, F.; Williamson, J.; Yang, W.Q.; Cline, W.O.; Beaudry, R. Blueberry Producers' Attitudes toward Harvest Mechanization for Fresh Market. Horttechnology 2018, 28, 10-16. [CrossRef]

6. Ehlenfeldt, M.K.; Martin, R.B. A survey of fruit firmness in highbush blueberry and species-introgressed blueberry cultivars. HortScience 2002, 37, 386-389.

7. Olmstead, J.W.; Finn, C.E. Breeding highbush blueberry cultivars adapted to machine harvest for the fresh market. Horttechnology 2014, 24, 290-294.

8. Berger, C.N.; Sodha, S.V.; Shaw, R.K.; Griffin, P.M.; Pink, D.; Hand, P.; Frankel, G. Fresh fruit and vegetables as vehicles for the transmission of human pathogens. Environ. Microbiol. 2010, 12, 2385-2397. [CrossRef] [PubMed]

9. Taylor, P.; Chen, P.M.; Spotts, R.A. Changes in Ripening Behaviors of 1-MCP-Treated 'd' Anjou' Pears After Storage Changes in Ripening Behaviors of 1-MCP-Treated 'd' Anjou' Pears After Storage. Int. J. Fruit Sci. 2005, 5, 3-18. [CrossRef]

10. Moggia, C.; Graell, J.; Lara, I.; González, G.; Lobos, G.A. Firmness at Harvest Impacts Postharvest Fruit Softening and Internal Browning Development in Mechanically Damaged and Non-damaged Highbush Blueberries (Vaccinium corymbosum L.). Front. Plant Sci. 2017, 8. [CrossRef] [PubMed]

11. Mehra, L.K.; MacLean, D.D.; Savelle, A.T.; Scherm, H. Postharvest Disease Development on Southern Highbush Blueberry Fruit in Relation to Berry Flesh Type and Harvest Method. Plant Dis. 2013, 97, $213-221$. [CrossRef]

12. Giongo, L.; Poncetta, P.; Loretti, P.; Costa, F. Texture profiling of blueberries (Vaccinium spp.) during fruit development, ripening and storage. Postharvest Biol. Technol. 2013, 76, 34-39. [CrossRef]

13. Gilbert, J.L.; Guthart, M.J.; Gezan, S.A.; Pisaroglo de Carvalho, M.; Schwieterman, M.L.; Colquhoun, T.A.; Bartoshuk, L.M.; Sims, C.A.; Clark, D.G.; Olmstead, J.W. Identifying Breeding Priorities for Blueberry Flavor Using Biochemical, Sensory, and Genotype by Environment Analyses. PLoS ONE 2015, 10, e0138494. [CrossRef] [PubMed]

14. Saftner, R.; Polashock, J.; Ehlenfeldt, M.; Vinyard, B. Instrumental and sensory quality characteristics of blueberry fruit from twelve cultivars. Postharvest Biol. Technol. 2008, 49, 19-26. [CrossRef]

15. Blaker, K.M.; Olmstead, J.W. Stone cell frequency and cell area variation of crisp and standard texture southern highbush blueberry fruit. J. Am. Soc. Hortic. Sci. 2014, 139, 553-557.

16. Forney, C.F.; Kalt, W.; Jordan, M.A.; Vinqvist-Tymchuk, M.R.; Fillmore, S.A.E. Blueberry and cranberry fruit composition during development. J. Berry Res. 2012, 2, 169-177. [CrossRef]

17. Chen, H.; Cao, S.; Fang, X.; Mu, H.; Yang, H.; Wang, X.; Xu, Q.; Gao, H. Changes in fruit firmness, cell wall composition and cell wall degrading enzymes in postharvest blueberries during storage. Sci. Hortic. (Amsterdam) 2015, 188, 44-48. [CrossRef] 
18. Wang, D.; Yeats, T.H.; Uluisik, S.; Rose, J.K.C.; Seymour, G.B. Fruit Softening: Revisiting the Role of Pectin. Trends Plant Sci. 2018, 23, 302-310. [CrossRef] [PubMed]

19. Cellon, C.; Amadeu, R.R.; Olmstead, J.W.; Mattia, M.R.; Ferrao, L.F.V.; Munoz, P.R. Estimation of genetic parameters and prediction of breeding values in an autotetraploid blueberry breeding population with extensive pedigree data. Euphytica 2018, 214, 87. [CrossRef]

20. Bell, H.P.; Burchill, J. Flower development in the lowbush blueberry. Can. J. Bot. 1955, 33, 251-258. [CrossRef]

21. Gough, R.E. The Highbush Blueberry and Its Management; Food Products Press: Binghamton, NY, USA, 1994.

22. Chu, W.; Gao, H.; Chen, H.; Wu, W.; Fang, X. Changes in Cuticular Wax Composition of Two Blueberry Cultivars during Fruit Ripening and Postharvest Cold Storage. J. Agric. Food Chem. 2018, 66, 2870-2876. [CrossRef] [PubMed]

23. Godoy, C.; Monterubbianesi, G.; Tognetti, J. Analysis of highbush blueberry (Vaccinium corymbosum L.) fruit growth with exponential mixed models. Sci. Hortic. (Amsterdam) 2008, 115, 368-376. [CrossRef]

24. Jorquera-Fontena, E.; Génard, M.; Franck, N. Analysis of blueberry (Vaccinium corymbosum L.) fruit water dynamics during growth using an ecophysiological model. J. Hortic. Sci. Biotechnol. 2017, 92, 646-659. [CrossRef]

25. Janick, J.; Paull, R.E. The Encyclopedia of Fruit and Nuts; CAB International: Wallingford, UK, 2008.

26. Liu, M.; Pirrello, J.; Chervin, C.; Roustan, J.-P.; Bouzayen, M. Ethylene control of fruit ripening: Revisiting the complex network of transcriptional regulation. Plant Physiol. 2015, 169, 2380-2390. [CrossRef] [PubMed]

27. Kumar, R.; Khurana, A.; Sharma, A.K. Role of plant hormones and their interplay in development and ripening of fleshy fruits. J. Exp. Bot. 2013, 65, 4561-4575. [CrossRef] [PubMed]

28. Haji, T.; Yaegaki, H.; Yamaguchi, M. Softening of stony hard peach by ethylene and the induction of endogenous ethylene by 1-aminocyclopropane-1-carboxylic acid (ACC). J. Jpn. Soc. Hortic. Sci. 2003, 72, 212-217. [CrossRef]

29. Hoeberichts, F.A.; Van Der Plas, L.H.W.; Woltering, E.J. Ethylene perception is required for the expression of tomato ripening-related genes and associated physiological changes even at advanced stages of ripening. Postharvest Biol. Technol. 2002, 26, 125-133. [CrossRef]

30. Suzuki, A.; Kikuchi, T.; Aoba, K. Changes of ethylene evolution, ACC content, ethylene forming enzyme activity and respiration in fruits of highbush blueberry. J. Jpn. Soc. Hortic. Sci. 1997, 66, 23-27. [CrossRef]

31. Ban, T.; Kugishima, M.; Ogata, T.; Shiozaki, S.; Horiuchi, S.; Ueda, H. Effect of ethephon (2-chloroethylphosphonic acid) on the fruit ripening characters of rabbiteye blueberry. Sci. Hortic. (Amsterdam) 2007, 112, 278-281. [CrossRef]

32. Costa, D.V.T.A.; Pintado, M.; Almeida, D.P.F. Postharvest ethylene application affects anthocyanin content and antioxidant activity of blueberry cultivars. ISHS Acta Hortic. 2014, 1017, 525-530. [CrossRef]

33. Chiabrando, V.; Giacalone, G. Shelf-life extension of highbush blueberry using 1-methylcyclopropene stored under air and controlled atmosphere. Food Chem. 2011, 126, 1812-1816. [CrossRef] [PubMed]

34. Wang, S.; Zhou, Q.; Zhou, X.; Wei, B.; Ji, S. The effect of ethylene absorbent treatment on the softening of blueberry fruit. Food Chem. 2018, 246, 286-294. [CrossRef] [PubMed]

35. DeLong, J.M.; Prange, R.K.; Bishop, C.; Harrison, P.A.; Ryan, D.A.J. The influence of 1-MCP on shelf-life quality of highbush blueberry. HortScience 2003, 38, 417-418.

36. Deng, J.; Shi, Z.; Li, X.; Liu, H. Effects of cold storage and 1-methylcyclopropene treatments on ripening and cell wall degrading in rabbiteye blueberry (Vaccinium ashei) fruit. Food Sci. Technol. Int. 2014, 20, 287-298. [CrossRef] [PubMed]

37. Blaker, K.M.; Olmstead, J.W. Effects of Preharvest Applications of 1-Methylcyclopropene on Fruit Firmness in Southern Highbush Blueberry. ISHS Acta Hortic. 2014, 1017, 71-75. [CrossRef]

38. MacLean, D.D.; NeSmith, D.S. Rabbiteye blueberry postharvest fruit quality and stimulation of ethylene production by 1-methylcyclopropene. HortScience 2011, 46, 1278-1281.

39. Sun, Y.; Hou, Z.; Su, S.; Yuan, J. Effects of ABA, GA3 and NAA on fruit development and anthocyanin accumulation in blueberry. J. South China Agric. Univ. 2013, 34, 6-11.

40. Buran, T.J.; Sandhu, A.K.; Azeredo, A.M.; Bent, A.H.; Williamson, J.G.; Gu, L. Effects of exogenous abscisic acid on fruit quality, antioxidant capacities, and phytochemical contents of southern high bush blueberries. Food Chem. 2012, 132, 1375-1381. [CrossRef] [PubMed]

41. Brummell, D.A. Cell wall disassembly in ripening fruit. Funct. Plant Biol. 2006, 33, 103. [CrossRef] 
42. Cell, P.; Sørensen, I.; Willats, W.G.T. The Plant Cell Wall; Humana Press: Totowa, NJ, USA, 2011; Volume 715, pp. 115-121. ISBN 978-1-61779-007-2.

43. Daher, F.B.; Braybrook, S.A. How to let go: Pectin and plant cell adhesion. Front. Plant Sci. 2015, 6. [CrossRef] [PubMed]

44. Carpita, N.C.; Gibeaut, D.M. Structural models of primary cell walls in flowering plants: Consistency of molecular structure with the physical properties of the walls during growth. Plant J. 1993, 3, 1-30. [CrossRef] [PubMed]

45. Huber, D.J. Polyuronide degradation and hemicellulose modifications in ripening tomato fruit. J. Am. Soc. Hortic. Sci. 1983, 108, 405-409.

46. Cutillas-Iturralde, A.; Zarra, I.; Fry, S.C.; Lorences, E.P. Implication of persimmon fruit hemicellulose metabolism in the softening process. Importance of xyloglucan endotransglycosylase. Physiol. Plant. 1994, 91, 169-176. [CrossRef]

47. Brummell, D.A.; Schröder, R. Xylan metabolism in primary cell walls. N. Z. J. For. Sci. 2009, 39, 125-143.

48. Atkinson, R.G.; Sutherland, P.W.; Johnston, S.L.; Gunaseelan, K.; Hallett, I.C.; Mitra, D.; Brummell, D.A.; Schröder, R.; Johnston, J.W.; Schaffer, R.J. Down-regulation of POLYGALACTURONASE1 alters firmness, tensile strength and water loss in apple (Malus $x$ domestica) fruit. BMC Plant Biol. 2012, 12, 129. [CrossRef] [PubMed]

49. Vicente, A.R.; Ortugno, C.; Rosli, H.; Powell, A.L.T.; Greve, L.C.; Labavitch, J.M. Temporal Sequence of Cell Wall Disassembly Events in Developing Fruits. 2. Analysis of Blueberry (Vaccinium Species). J. Agric. Food Chem. 2007, 55, 4125-4130. [CrossRef] [PubMed]

50. Beaudry, R.; Hanson, E.J.; Beggs, J.L.; Beaudry, R.M. Applying Calcium Chloride Postharvest to Improve Highbush Blueberry Firmness Applying Calcium Chloride Postharvest to Improve Highbush Blueberry Firmness. HortScience 2016, 28, 2-4.

51. Angeletti, P.; Castagnasso, H.; Miceli, E.; Terminiello, L.; Concellón, A.; Chaves, A.; Vicente, A.R. Effect of preharvest calcium applications on postharvest quality, softening and cell wall degradation of two blueberry (Vaccinium corymbosum) varieties. Postharvest Biol. Technol. 2010, 58, 98-103. [CrossRef]

52. Buchanan, B.B.; Gruissem, W.; Jones, R.L. Biochemistry \& Molecular Biology of Plants; American Society of Plant Physiologists: Rockville, MD, USA, 2000; Volume 40.

53. Lara, I.; García, P.; Vendrell, M. Modifications in cell wall composition after cold storage of calcium-treated strawberry (Fragaria $\times$ ananassa Duch.) fruit. Postharvest Biol. Technol. 2004, 34, 331-339. [CrossRef]

54. Conway, W.S.; Sams, C.E. The effects of postharvest infiltration of calcium, magnesium, or strontium on decay, firmness, respiration, and ethylene production in apples. J. Am. Soc. Hortic. Sci. 1987, 112, 300-303.

55. Conway, W.S. Possible Mechanisms by Which Postharvest Calcium Treatment Reduces Decay in Apples. Phytopathology 1984, 74, 208. [CrossRef]

56. Sams, C.E.; Conway, W.S.; Abbott, J.A.; Lewis, R.J.; Ben-Shalom, N. Firmness and decay of apples following postharvest pressure infiltration of calcium and heat treatment. J. Am. Soc. Hortic. Sci. 1993, 118, 623-627.

57. Al-Banna, M.K.S.; Jinks, J.L. Indirect selection for environmental sensitivity in Nicotiana rustica. Hered. (Edinb) 1984, 52, 297-301. [CrossRef]

58. Bonomelli, C.; Ruiz, R. Effects of foliar and soil calcium application on yield and quality of table grape cv.'Thompson Seedless'. J. Plant Nutr. 2010, 33, 299-314. [CrossRef]

59. Ciccarese, A.; Stellacci, A.M.; Gentilesco, G.; Rubino, P. Effectiveness of pre-and post-veraison calcium applications to control decay and maintain table grape fruit quality during storage. Postharvest Biol. Technol. 2013, 75, 135-141. [CrossRef]

60. García, J.M.; Herrera, S.; Morilla, A. Effects of Postharvest Dips in Calcium Chloride on Strawberry. J. Agric. Food Chem. 1996, 44, 30-33. [CrossRef]

61. Hernández-Muñoz, P.; Almenar, E.; Ocio, M.J.; Gavara, R. Effect of calcium dips and chitosan coatings on postharvest life of strawberries (Fragaria $x$ ananassa). Postharvest Biol. Technol. 2006, 39, 247-253. [CrossRef]

62. Hernández-Muñoz, P.; Almenar, E.; Del Valle, V.; Velez, D.; Gavara, R. Effect of chitosan coating combined with postharvest calcium treatment on strawberry (Fragaria $x$ ananassa) quality during refrigerated storage. Food Chem. 2008, 110, 428-435. [CrossRef] [PubMed]

63. Lombard, V.; Golaconda Ramulu, H.; Drula, E.; Coutinho, P.M.; Henrissat, B. The carbohydrate-active enzymes database (CAZy) in 2013. Nucleic Acids Res. 2014, 42, 490-495. [CrossRef] [PubMed] 
64. Gupta, V.; Estrada, A.D.; Blakley, I.; Reid, R.; Patel, K.; Meyer, M.D.; Andersen, S.U.; Brown, A.F.; Lila, M.A.; Loraine, A.E. RNA-Seq analysis and annotation of a draft blueberry genome assembly identifies candidate genes involved in fruit ripening, biosynthesis of bioactive compounds, and stage-specific alternative splicing. Gigascience 2015, 4, 5. [CrossRef] [PubMed]

65. Cantarel, B.L.; Coutinho, P.M.; Rancurel, C.; Bernard, T.; Lombard, V.; Henrissat, B. The Carbohydrate-Active EnZymes database (CAZy): An expert resource for glycogenomics. Nucleic Acids Res. 2008, 37 (Suppl. 1), D233-D238. [CrossRef] [PubMed]

66. Yin, Y.; Mao, X.; Yang, J.; Chen, X.; Mao, F.; Xu, Y. dbCAN: A web resource for automated carbohydrate-active enzyme annotation. Nucleic Acids Res. 2012, 40, W445-W451. [CrossRef] [PubMed]

67. Asif, M.H.; Lakhwani, D.; Pathak, S.; Gupta, P.; Bag, S.K.; Nath, P.; Trivedi, P.K. Transcriptome analysis of ripe and unripe fruit tissue of banana identifies major metabolic networks involved in fruit ripening process. BMC Plant Biol. 2014, 14, 316. [CrossRef] [PubMed]

68. Rose, J.K.C.; Bennett, A.B. Cooperative disassembly of the cellulose-xyloglucan network of plant cell walls: Parallels between cell expansion and fruit ripening. Trends Plant Sci. 1999, 4, 176-183. [CrossRef]

69. Goulao, L.F.; Oliveira, C.M. Cell wall modifications during fruit ripening: When a fruit is not the fruit. Trends Food Sci. Technol. 2008, 19, 4-25. [CrossRef]

70. Chandrasekar, B.; van der Hoorn, R.A.L. Beta galactosidases in Arabidopsis and tomato-A mini review. Biochem. Soc. Trans. 2016, 44, 150-158. [CrossRef] [PubMed]

71. Hossain, M.A.; Rana, M.M.; Kimura, Y.; Roslan, H.A. Changes in Biochemical Characteristics and Activities of Ripening Associated Enzymes in Mango Fruit during the Storage at Different Temperatures. Biomed Res. Int. 2014, 2014, 1-11. [CrossRef] [PubMed]

72. Uluisik, S.; Chapman, N.H.; Smith, R.; Poole, M.; Adams, G.; Gillis, R.B.; Besong, T.M.D.; Sheldon, J.; Stiegelmeyer, S.; Perez, L.; et al. Genetic improvement of tomato by targeted control of fruit softening. Nat. Biotechnol. 2016, 34, 950-952. [CrossRef] [PubMed]

73. Wu, B.; Gao, L.; Gao, J.; Xu, Y.; Liu, H.; Cao, X.; Zhang, B.; Chen, K. Genome-Wide Identification, Expression Patterns, and Functional Analysis of UDP Glycosyltransferase Family in Peach (Prunus persica L. Batsch). Front. Plant Sci. 2017, 8. [CrossRef] [PubMed]

74. Carbone, F.; Preuss, A.; De Vos, R.C.H.; D’Amico, E.; Perrotta, G.; Bovy, A.G.; Martens, S.; Rosati, C. Developmental, genetic and environmental factors affect the expression of flavonoid genes, enzymes and metabolites in strawberry fruits. Plant. Cell Environ. 2009, 32, 1117-1131. [CrossRef] [PubMed]

75. Paniagua, A.C.; East, A.R.; Hindmarsh, J.P.; Heyes, J.A. Moisture loss is the major cause of firmness change during postharvest storage of blueberry. Postharvest Biol. Technol. 2013, 79, 13-19. [CrossRef]

76. Moggia, C.; Beaudry, R.M.; Retamales, J.B.; Lobos, G.A. Variation in the impact of stem scar and cuticle on water loss in highbush blueberry fruit argue for the use of water permeance as a selection criterion in breeding. Postharvest Biol. Technol. 2017, 132, 88-96. [CrossRef]

77. Moggia, C.; Graell, J.; Lara, I.; Schmeda-Hirschmann, G.; Thomas-Valdés, S.; Lobos, G.A. Fruit characteristics and cuticle triterpenes as related to postharvest quality of highbush blueberries. Sci. Hortic. (Amsterdam). 2016, 211, 449-457. [CrossRef]

78. Sun, X.; Narciso, J.; Wang, Z.; Ference, C.; Bai, J.; Zhou, K. Effects of Chitosan-Essential Oil Coatings on Safety and Quality of Fresh Blueberries. J. Food Sci. 2014, 79. [CrossRef] [PubMed]

79. Abugoch, L.; Tapia, C.; Plasencia, D.; Pastor, A.; Castro-Mandujano, O.; López, L.; Escalona, V.H. Shelf-life of fresh blueberries coated with quinoa protein/chitosan/sunflower oil edible film. J. Sci. Food Agric. 2016, 96, 619-626. [CrossRef] [PubMed]

80. Harker, F.R.; Redgwell, R.J.; Hallett, I.C.; Murray, S.H.; Carter, G. Chapter 2: Texture of fresh fruit. In Horticultural Reviews; Janick, J., Ed.; Wiley Online Library: Hoboken, NJ, USA, 1997; Volume 20, pp. 121-224.

81. Allan-Wojtas, P.M.; Forney, C.F.; Carbyn, S.E.; Nicholas, K.U.K.G. Microstructural Indicators of Quality-related Characteristics of Blueberries-An Integrated Approach. LWT_Food Sci. Technol. 2001, 34, 23-32. [CrossRef]

82. Fava, J.; Alzamora, S.M.; Castro, M.A. Structure and Nanostructure of the Outer Tangential Epidermal Cell Wall in Vaccinium corymbosum L. (Blueberry) Fruits by Blanching, Freezing-Thawing and Ultrasound. Food Sci. Technol. Int. 2006, 12, 241-251. [CrossRef]

83. Blaker, K.M. Comparison of Crisp and Standard Fruit Texture in Southern Highbush Blueberry Using Instrumental and Sensory Panel Techniques; University of Florida: Gainesville, FL, USA, 2013; ISBN 1303820617. 
84. Abbott, J.; Watada, A.E.; Massie, D.R. Effe-gi, Magness-Taylor, and Instron fruit pressure testing devices for apples, peaches, and nectarines. J. Am. Soc. Hortic. Sci. 1976, 101, 698-700.

85. Mason, H.; Mason, A. Apple Tree Named “Rosy Glow”. U.S. Patent 10/712,783, 26 August 2004.

86. Braun, T. Apple tree named 'Fuji Fubrax'. U.S. Patent 11/355,401, 29 April 2008.

87. Schmider, E.; Braun, T. Apple tree named Golden Parsi. U.S. Patent 12/798,834, 13 October 2011.

88. Maillard, A.; Maillard, L. Apple tree named 'REGALSTAR'. U.S. Patent 13/999,809, 31 May 2016.

89. Harker, F.R.; Maindonald, J.H.; Jackson, P.J. Penetrometer Measurement of Apple and Kiwifruit Firmness: Operator and Instrument Differences. J. Am. Soc. Hortic. Sci. 1996, 121, 927-936.

90. Lehman-Salada, L. Instrument and operator effects on apple firmness readings. HortScience 1996, 31, $994-997$.

91. De Belie, N.; Schotte, S.; Coucke, P.; De Baerdemaeker, J. Development of an automated monitoring device to quantify changes in firmness of apples during storage. Postharvest Biol. Technol. 2000, 18, 1-8. [CrossRef]

92. Plocharski, W.; Konopacka, D.; Zwierz, J. Comparison of Magness-Taylor's pressure test with mechanical, non-destructive methods of apple and pear firmness measurements. Int. Agrophys. 2000, 14, 311-318.

93. Abbott, J.A.; Liljedahl, L.A. Relationship of sonic resonant frequency to compression tests and Magness-Taylor firmness of apples during refrigerated storage. Trans. ASAE 1994, 37, 1211-1215. [CrossRef]

94. Abbott, J.A.; Massie, D.R.; Upchurch, B.L.; Hruschka, W.R. Nondestructive sonic firmness measurement of apples. Trans. ASAE 1995, 38, 1461-1466. [CrossRef]

95. Lu, R.; Peng, Y. Hyperspectral scattering for assessing peach fruit firmness. Biosyst. Eng. 2006, 93, $161-171$. [CrossRef]

96. Abbott, J.A. Firmness Measurement of Freshly Harvested 'Delicious' Apples by Sensory Methods, Sonic Transmission, Magness-Taylor, and Compression. J. Am. Soc. Hortic. Sci. 1994, 119, 510-515.

97. Elmasry, G.; Wang, N.; Vigneault, C. Postharvest Biology and Technology Detecting chilling injury in Red Delicious apple using hyperspectral imaging and neural networks. Postharvest Biol. Technol. 2009, 52, 1-8. [CrossRef]

98. Lu, R. Multispectral imaging for predicting firmness and soluble solids content of apple fruit. Postharvest Biol. Technol. 2004, 31, 147-157. [CrossRef]

99. Finn, C.E.; Luby, J.J. Inheritance of fruit quality traits in blueberry. J. Am. Soc. Hortic. Sci. 1992, 117, 617-621.

100. Ali, S.; Zaman, Q.U.; Schumann, A.W.; Udenigwe, C.C.; Farooque, A.A. Impact of fruit ripening parameters on harvesting efficiency of the wild blueberry harvester. In ASABE Annual International Meeting; American Society of Agricultural and Biological Engineers: St. Joseph, MI, USA, 2016.

101. Vilela, A.; Gonçalves, B.; Ribeiro, C.; Fonseca, A.T.; Correia, S.; Fernandes, H.; Ferreira, S.; Bacelar, E.; Silva, A.P. Study of Textural, Chemical, Color and Sensory Properties of Organic Blueberries Harvested in Two Distinct Years: A Chemometric Approach. J. Texture Stud. 2016, 47, 199-207. [CrossRef]

102. Concha-Meyer, A.; Eifert, J.D.; Williams, R.C.; Marcy, J.E.; Welbaum, G.E. Shelf life determination of fresh blueberries (Vaccinium corymbosum) stored under controlled atmosphere and ozone. Int. J. food Sci. 2015. [CrossRef] [PubMed]

103. Hu, M.-H.; Dong, Q.-L.; Liu, B.-L.; Opara, U.L. Prediction of mechanical properties of blueberry using hyperspectral interactance imaging. Postharvest Biol. Technol. 2016, 115, 122-131. [CrossRef]

104. Brazelton, D.M.; Wagner, A.L. Blueberry Plant Named 'Last Call'. 2015. Available online: https://patents. google.com/patent/USPP25386P3 (accessed on 15 August 2018).

105. NeSmith, D.S. 'Suziblue'Southern Highbush Blueberry. HortScience 2010, 45, 142-143.

106. Grajkowski, J.; Ochman, I.; Muliński, Z. Firmness and antioxidant capacity of highbush blueberry (Vaccinium corymbosum L.) grown on three types of organic bed. Veg. Crop. Res. Bull. 2007, 66, 155-159. [CrossRef]

107. Blaker, K.M.; Plotto, A.; Baldwin, E.A.; Olmstead, J.W. Correlation between sensory and instrumental measurements of standard and crisp-texture southern highbush blueberries (Vaccinium corymbosum L. interspecific hybrids). J. Sci. Food Agric. 2014, 94, 2785-2793. [CrossRef] [PubMed]

108. NeSmith, D.S.; Draper, A.D.; Spiers, J.M. Palmetto'Southern Highbush Blueberry. HortScience 2004, 39, 1774-1775.

109. Pavlis, G.C. Blueberry fruit quality and yield as affected by fertilization. ISHS Acta Hortic. 2004, 353-356. [CrossRef]

110. Ochmian, I.; Grajkowski, J.; Skupieñ, K. Effect of substrate type on the field performance and chemical composition of highbush blueberry cv. Patriot. Agric. Food Sci. 2010, 19, 69-80. [CrossRef] 
111. Retamales, J.B.; Lobos, G.A.; Romero, S.; Godoy, R.; Moggia, C. Repeated applications of CPPU on highbush blueberry cv. Duke increase yield and enhance fruit quality at harvest and during postharvest. Chil. J. Agric. Res. 2014, 74, 157-161. [CrossRef]

112. Yu, P.; Li, C.; Takeda, F.; Krewer, G. Visual bruise assessment and analysis of mechanical impact measurement in southern highbush blueberries. Appl. Eng. Agric. 2014, 30, 29-37. [CrossRef]

113. Stringer, S.J.; Draper, A.D.; Spiers, J.M.; Marshall, D.A.; Smith, B.J. 'Pearl'Southern Highbush Blueberry. HortScience 2013, 48, 130-131.

114. Lobos, G.A.; Callow, P.; Hancock, J.F. The effect of delaying harvest date on fruit quality and storage of late highbush blueberry cultivars (Vaccinium corymbosum L.). Postharvest Biol. Technol. 2014, 87, 133-139. [CrossRef]

115. Ehret, D.L.; Frey, B.; Forge, T.; Helmer, T.; Bryla, D.R. Effects of drip irrigation configuration and rate on yield and fruit quality of young highbush blueberry plants. HortScience 2012, 47, 414-421.

116. Hicklenton, P.; Forney, C.; Domytrak, C. Use of row covers and post harvest storage techniques to alter maturity and marketing period for highbush blueberries. ISHS Acta Hortic. 2002, 287-295. [CrossRef]

117. Sargent, S.A.; Berry, A.D.; Brecht, J.K.; Santana, M.; Zhang, S.; Ristow, N. Studies on quality of southern highbush blueberry cultivars: Effects of pulp temperature, impact and hydrocooling. ISHS Acta Hortic. 2017, 1180, 497-502. [CrossRef]

118. Brazelton, D.M.; Wagner, A.L. Blueberry Plant named'CLOCKWORK'. 2013. Available online: https: / / patents.google.com/patent/US20130239264P1 (accessed on 15 August 2018).

119. Yang, W.Q.; Andrews, H.E.; Basey, A. Blueberry rootstock: Selection, evaluation, and field performance of grafted blueberry plants. ISHS Acta Hortic. 2016, 1117, 119-124. [CrossRef]

120. Brazelton, D.M.; Wagner, A.L. Blueberry Plant Named 'Cargo' 2014. Available online: https://patents. google.com/patent/US20130239260P1 (accessed on 15 August 2018).

121. Brazelton, D.M.; Wagner, A.L. Blueberry Plant Named ‘Blue Ribbon' 2014. Available online: https:/ / patents. google.com/patent/US20130239265P1 (accessed on 15 August 2018).

122. Brazelton, D.M.; Wagner, A.L. Blueberry Plant Named 'Top Shelf' 2014. Available online: https:/ / patents. google.com/patent/US20130239261P1 (accessed on 15 August 2018).

123. Moggia, C.; González, C.; Lobos, G.A.; Bravo, C.; Valdés, M.; Lara, I.; Graell, J. Changes in quality and maturity of 'Duke' and 'Brigitta' blueberries during fruit development: Postharvest implications. Acta Hortic. 2018, 1194, 1495-1501. [CrossRef]

124. Patel, N. Blueberry Plant Named 'Hortblue Poppins' 2011. Available online: https:/ / patents.google.com/ patent/USPP21881P3 (accessed on 15 August 2018).

125. Ballington, J.R.; Bland, W.T. Blueberry Plant Named 'Heintooga' 2017. Available online: https:/ / patents. google.com/patent/US20170188494P1 (accessed on 15 August 2018).

126. Strik, B.C.; Vance, A.J.; Finn, C.E. Northern Highbush Blueberry Cultivars Differed in Yield and Fruit Quality in Two Organic Production Systems from Planting to Maturity. HortScience 2017, 52, 844-851. [CrossRef]

127. Rodríguez-Armenta, H.P.; Olmstead, J.W.; Lyrene, P.M. Characterization of backcross blueberry populations created to introgress Vaccinium arboreum traits into southern highbush blueberry. ISHS Acta Hortic. 2016, 1180, 435-444. [CrossRef]

128. Ballington, J.; Rooks, S. Blueberry Named 'Carteret' 2007. Available online: https:/ / patents.google.com/ patent/US20070143882 (accessed on 15 August 2018).

129. Ballington, J.; Rooks, S. Blueberry named 'New Hanover' 2007. Available online: https:/ / patents.google. com/patent/USPP19990P3 (accessed on 15 August 2018).

130. Ballington, J.R.; Rooks, S.D. Blueberry named 'Robeson' 2009. Available online: https:/ / patents.google.com/ patent/USPP19756P3 (accessed on 15 August 2018).

131. Almutairi, K.; Bryla, D.R.; Strik, B.C. Potential of Deficit Irrigation, Irrigation Cutoffs, and Crop Thinning to Maintain Yield and Fruit Quality with Less Water in Northern Highbush Blueberry. HortScience 2017, 52, 625-633. [CrossRef]

132. Strik, B.; Buller, G. Nitrogen fertilization rate, sawdust mulch, and pre-plant incorporation of sawdust-term impact on yield, fruit quality, and soil and plant nutrition in 'elliott'. ISHS Acta Hortic. 2014, 1017, 269-275. [CrossRef]

133. NeSmith, D.S.; Prussia, S.; Tetteh, M.; Krewer, G. Firmness losses of rabbiteye blueberries (Vaccinium ashei Reade) during harvesting and handling. ISHS Acta Hortic. 2000, 287-293. [CrossRef] 
134. Yang, W.Q.; Harpole, J.; Finn, C.E.; Strik, B.C. Evaluating berry firmness and total soluble solids of newly released highbush blueberry cultivars. ISHS Acta Hortic. 2008, 863-868. [CrossRef]

135. Li, C.; Luo, J.; MacLean, D. A novel instrument to delineate varietal and harvest effects on blueberry fruit texture during storage. J. Sci. Food Agric. 2011, 91, 1653-1658. [CrossRef] [PubMed]

136. NeSmith, D.S.; Draper, A.D. ‘Camellia'southern highbush blueberry. J. Am. Pomol. Soc. 2007, 61, 34-37.

137. NeSmith, D.S.; Nunez-Barrios, A.; Prussia, S.E.; Aggarwal, D. Postharvest berry quality of six rabbiteye blueberry cultivars in response to temperature. J. Am. Pomol. Soc. 2005, 59, 13-17.

138. Døving, A.; Måge, F.; Vestrheim, S. Methods for Testing Strawberry Fruit Firmness Methods for Testing Strawberry Fruit Firmness: A Review. Small Fruits Rev. 2008, 8851, 37-41. [CrossRef]

139. Ballington, J.R.; Ballinger, W.E.; Mainland, C.M.; Swallow, W.H.; Maness, E.P. Ripening period of Vaccinium species in southeastern North Carolina [Blueberry, breeding for both early-and late-ripening Vaccinium genotypes]. J. Am. Soc. Hortic. Sci. 1984, 109, 392-396.

140. Boches, P.; Bassil, N.V.; Rowland, L. Genetic diversity in the highbush blueberry evaluated with microsatellite markers. J. Am. Soc. Hortic. Sci. 2006, 131, 674-686.

141. Hancock, J.F.; Lyrene, P.; Finn, C.E.; Vorsa, N.; Lobos, G.A. Blueberries and cranberries. In Temperate Fruit Crop Breeding; James, F.H., Ed.; Springer: Berlin, Germany, 2008; pp. 115-150.

142. Goldy, R.G.; Lyrene, P.M. In vitro colchicine treatment of $4 \times$ blueberries, Vaccinium sp. [Polyploid induction, genotype effect]. J. Am. Soc. Hortic. Sci. 1984, 109, 336-338.

143. Chavez, D.J.; Lyrene, P.M. Effects of self-pollination and cross-pollination of Vaccinium darrowii (Ericaceae) and other low-chill blueberries. HortScience 2009, 44, 1538-1541.

144. Ehlenfeldt, M.K.; Draper, A.D.; Clark, J.R. Performance of southern highbush blueberry cultivars released by the US Department of Agriculture and cooperating state agricultural experiment stations. Horttechnology 1995, 5, 127-130.

145. Coville, F.V. Improving the wild blueberry. In Yearbook of Agriculture; U.S. Department of Agriculture; U.S. Government Printing Office: Washington, DC, USA, 1937; pp. 559-574.

146. Sharpe, R.H.; Sherman, W.B. "Floridablue and Sharpblue": Two new blueberries for central Florida. Circ. Fla Coop Ext. Serv. Inst. Food Agric. Sci. Univ. Fla 1976, 240, 6.

147. Fillion, L.; Kilcast, D. Consumer perception of crispness and crunchiness in fruits and vegetables. Food Qual. Prefer. 2002, 13, 23-29. [CrossRef]

148. Aalders, L.E.; Hall, I.V. A study of variation in fruit yield and related characters in two diallels of the lowbush blueberry, Vaccinium angustifolium Ait. Can. J. Genet. Cytol. 1975, 17, 401-404. [CrossRef]

149. Erb, W.A.; Draper, A.D.; Galletta, G.J.; Swartz, H.J. Combining ability for plant and fruit traits of interspecific blueberry progenies on mineral soil. J. Am. Soc. Hortic. Sci. 1990, 115, 1025-1028.

150. Scalzo, J.; Sguigna, V.; Mezzetti, B.; Stanley, J.; Alspach, P. Variation of fruit traits in highbush blueberry seedlings from a factorial cross. ISHS Acta Hortic. 2010, 79-83. [CrossRef]

151. Scalzo, J.; Stanley, J.; Alspach, P.; Mezzetti, B. Preliminary evaluation of fruit traits and phytochemicals in a highbush blueberry seedling population. J. Berry Res. 2013, 3, 103-111. [CrossRef]

152. Connor, A.M.; Luby, J.J.; Tong, C.B.S.; Finn, C.E.; Hancock, J.F. Genotypic and environmental variation in antioxidant activity, total phenolic content, and anthocyanin content among blueberry cultivars. J. Am. Soc. Hortic. Sci. 2002, 127, 89-97.

153. Finn, C.E.; Hancock, J.F.; Mackey, T.; Serce, S. Genotype $\times$ environment interactions in highbush blueberry (Vaccinium sp. L.) families grown in Michigan and Oregon. J. Am. Soc. Hortic. Sci. 2003, 128, 196-200.

154. Isik, F.; Holland, J.; Maltecca, C. Genetic Data Analysis for Plant and Animal Breeding; Springer: New York, NY, USA, 2017; Volume 1, ISBN 3319551779.

155. Hamblin, M.T.; Buckler, E.S.; Jannink, J.-L. Population genetics of genomics-based crop improvement methods. Trends Genet. 2011, 27, 98-106. [CrossRef] [PubMed]

156. Visscher, P.M.; Brown, M.A.; McCarthy, M.I.; Yang, J. Five years of GWAS discovery. Am. J. Hum. Genet. 2012, 90, 7-24. [CrossRef] [PubMed]

157. Jannink, J.-L.; Lorenz, A.J.; Iwata, H. Genomic selection in plant breeding: From theory to practice. Brief. Funct. Genom. 2010, 9, 166-177. [CrossRef] [PubMed]

158. Ferrão, L.F.V.; Benevenuto, J.; de Bem Oliveira, I.; Cellon, C.; Olmstead, J.; Kirst, M.; Resende, M.F.R.; Munoz, P. Insights into the genetic basis of blueberry fruit-related traits using diploid and polyploid models in a GWAS context. Front. Ecol. Evol. 2018, 6, 107. [CrossRef] 
159. Wang, W.; Cai, J.; Wang, P.; Tian, S.; Qin, G. Post-transcriptional regulation of fruit ripening and disease resistance in tomato by the vacuolar protease SIVPE3. Genom. Biol. 2017, 18, 47. [CrossRef] [PubMed]

160. Salentijn, E.M.J.; Aharoni, A.; Schaart, J.G.; Boone, M.J.; Krens, F.A. Differential gene expression analysis of strawberry cultivars that differ in fruit-firmness. Physiol. Plant. 2003, 118, 571-578. [CrossRef]

161. Roje, S. S-Adenosyl-1-methionine: Beyond the universal methyl group donor. Phytochemistry 2006, 67, 1686-1698. [CrossRef] [PubMed]

162. Paul, V.; Pandey, R.; Srivastava, G.C. The fading distinctions between classical patterns of ripening in climacteric and non-climacteric fruit and the ubiquity of ethylene-An overview. J. Food Sci. Technol. 2012, 49, 1-21. [CrossRef] [PubMed]

163. Van de Poel, B.; Bulens, I.; Oppermann, Y.; Hertog, M.L.A.T.M.; Nicolai, B.M.; Sauter, M.; Geeraerd, A.H. S-adenosyl-L-methionine usage during climacteric ripening of tomato in relation to ethylene and polyamine biosynthesis and transmethylation capacity. Physiol. Plant. 2013, 148, 176-188. [CrossRef] [PubMed]

164. Singh, R.; Rastogi, S.; Dwivedi, U.N. Phenylpropanoid Metabolism in Ripening Fruits. Compr. Rev. Food Sci. Food Saf. 2010, 9, 398-416. [CrossRef]

165. Moffatt, B.A.; Weretilnyk, E.A. Sustaining S-adenosyl-L-methionine-dependent methyltransferase activity in plant cells. Physiol. Plant. 2001, 113, 435-442. [CrossRef]

166. Tang, X.; Lowder, L.G.; Zhang, T.; Malzahn, A.A.; Zheng, X.; Voytas, D.F.; Zhong, Z.; Chen, Y.; Ren, Q.; Li, Q. A CRISPR-Cpf1 system for efficient genome editing and transcriptional repression in plants. Nat. Plants 2017, 3, 17018. [CrossRef] [PubMed]

167. Puchta, H. Applying CRISPR/Cas for genome engineering in plants: The best is yet to come. Curr. Opin. Plant Biol. 2017, 36, 1-8. [CrossRef] [PubMed]

168. Jaganathan, D.; Ramasamy, K.; Sellamuthu, G.; Jayabalan, S.; Venkataraman, G. CRISPR for Crop Improvement: An Update Review. Front. Plant Sci. 2018, 9. [CrossRef] [PubMed]

169. Peng, A.; Chen, S.; Lei, T.; Xu, L.; He, Y.; Wu, L.; Yao, L.; Zou, X. Engineering canker-resistant plants through CRISPR/Cas9-targeted editing of the susceptibility gene CsLOB1 promoter in citrus. Plant Biotechnol. J. 2017, 15, 1509-1519. [CrossRef] [PubMed]

170. Shi, J.; Gao, H.; Wang, H.; Lafitte, H.R.; Archibald, R.L.; Yang, M.; Hakimi, S.M.; Mo, H.; Habben, J.E. ARGOS8 variants generated by CRISPR-Cas9 improve maize grain yield under field drought stress conditions. Plant Biotechnol. J. 2017, 15, 207-216. [CrossRef] [PubMed] 